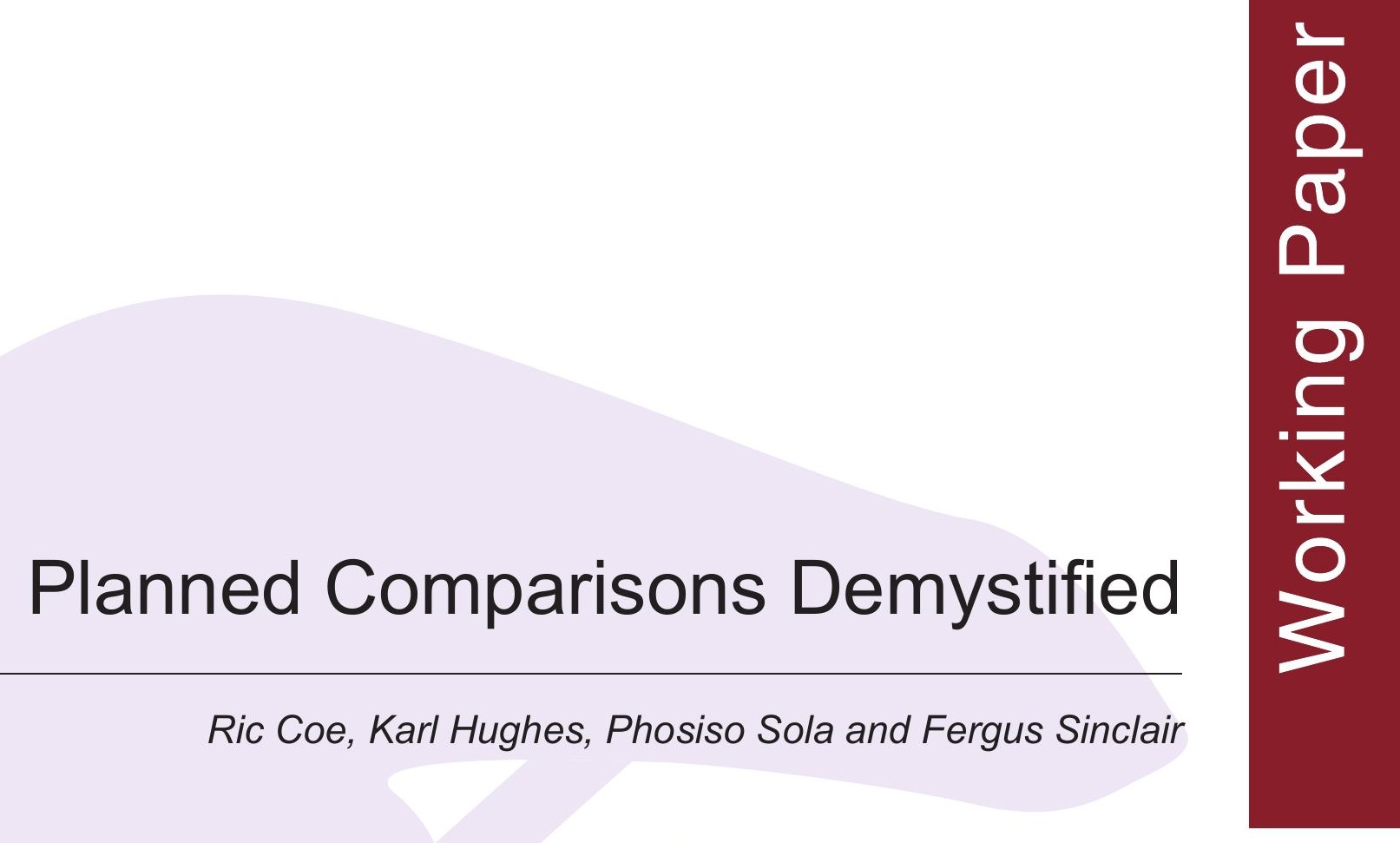




\section{Planned Comparisons Demystified}

Ric Coe, Karl Hughes, Phosiso Sola and Fergus Sinclair

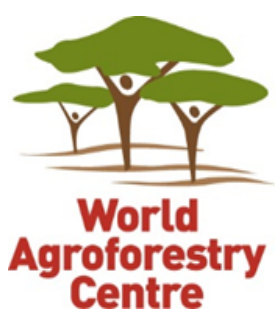




\section{LIMITED CIRCULATION}

World

Agroforestry

Centre

Correct citation: Coe R, Hughes K, Sola P. and Sinclair, F. 2017. Planned Comparisons Demystified. ICRAF Working Paper No 263. Nairobi, World Agroforestry Centre. DOI:

http://dx.doi.org/10.5716/WP17354.PDF

Titles in the Working Paper series aim to disseminate interim results on agroforestry research and practices, and stimulate feedback from the scientific community. Other publication series from the World Agroforestry Centre include: Technical Manuals, Occasional Papers and the Trees for Change Series.

Published by the World Agroforestry Centre

United Nations Avenue

PO Box 30677-00100, Nairobi, Kenya

Tel: +254 207224000 , via USA +16508336645

Email: worldagroforestry@cgiar.org

Website: www.worldagroforestry.org

(C) World Agroforestry Centre 2017

Working Paper No. 263

The views expressed in this publication are those of the author(s) and not necessarily those of the World Agroforestry Centre.

Articles appearing in this publication may be quoted or reproduced without charge, provided the source is acknowledged. All images remain the sole property of their source and may not be used for any purpose without written permission from the source. 


\section{Contents}

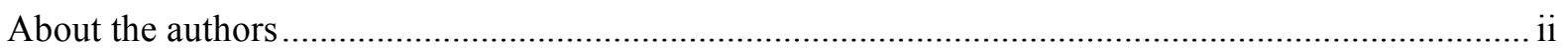

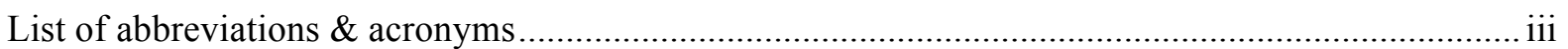

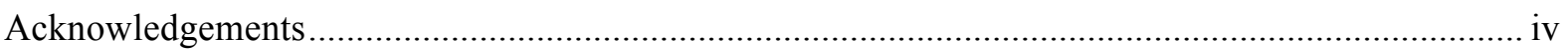

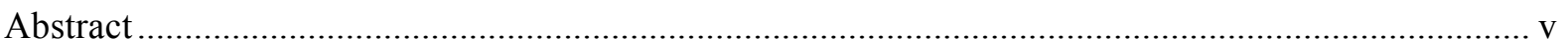

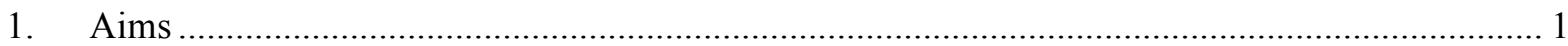

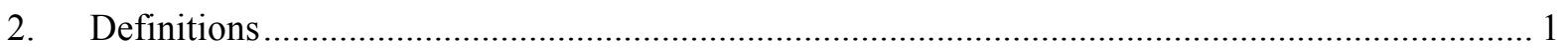

3. The core problem: research, development and the connections ........................................... 2

4. Conventional solutions to the core problem................................................................... 4

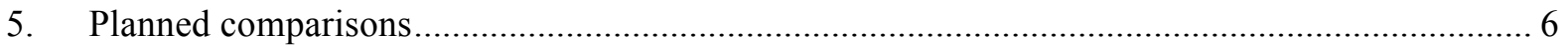

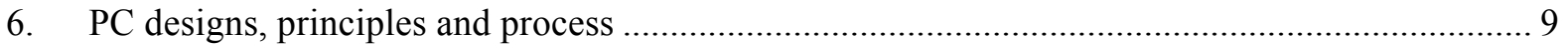

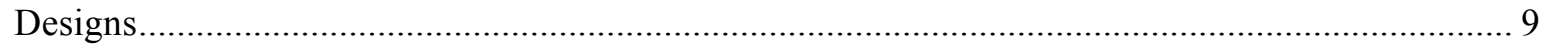

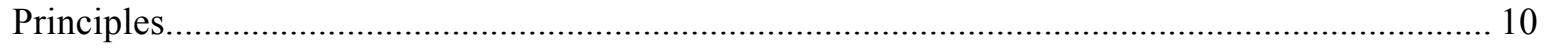

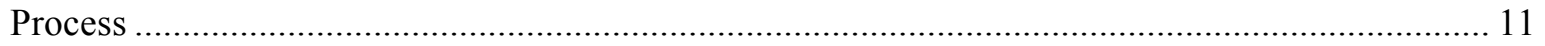

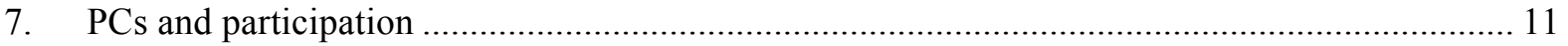

8. PCs and other modes of learning and research within development projects ........................ 12

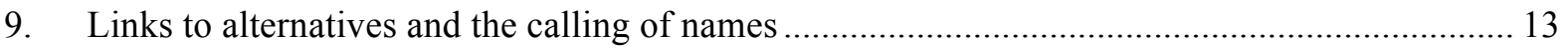

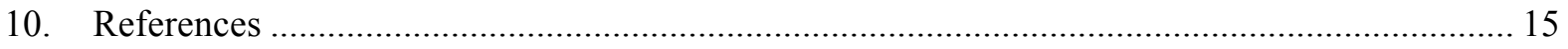

\section{List of tables}

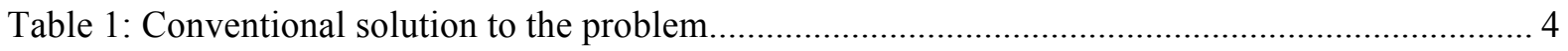

Table 2: Comparing options (species) in two contexts (niches) .................................................... 5

Table 3: Planned comparison approach to generating data for Table 2 …................................... 7

Table 4: PCs as a combination of other approaches ............................................................... 8

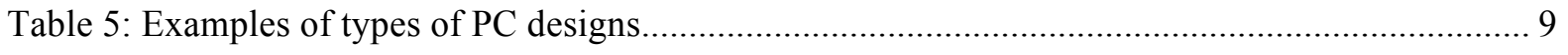

Table 6: Proposed alternative names for the PC concept ...................................................... 13

\section{List of figures}

Figure 1: The R in D approach, with the role of PCs highlighted ............................................. 6 


\section{About the authors}

Richard (Ric) Coe is a Principal Scientist at the World Agroforestry Centre (ICRAF) specializing in research methods. For the last 27 years he has been working with scientists from ICRAF and other CGIAR centres to help improve research effectiveness by bringing statistical ideas into research conception, design and analysis. In 2008 he took a simultaneous part-time position with the University of Reading, UK, and in 2016 helped establish the notfor-profit social enterprise, Statistics for Sustainable Development, where he is a director. Email: r.coe@,cgiar.org, r.coe@stats4sd.org

Karl Hughes is an Impact Evaluation and Monitoring and Evaluation (M\&E) specialist with over 20 years of experience in the international development sector, 16 of which were in Africa and Asia. He currently heads ICRAF's Impact Unit, which seeks to support, accelerate and evidence the effective and efficient translation of the organization's research efforts into inclusive and equitable development outcomes and impacts. Karl obtained his $\mathrm{PhD}$ focusing on impact evaluation methodology - from the London School of Hygiene and Tropical Medicine, University of London in 2012. He also holds a Masters in Environmental Studies (1998) from York University, Canada and a Bachelor's in Anthropology and Philosophy (1994), from the University of British Columbia, Canada. Email: k.hughes@cgiar.org

Phosiso Sola is the East Africa Coordinator of the Drylands Development Programme at ICRAF where she has been working with partners and fellow scientists to integrate research, institutional development and policy advocacy. She has over 20 years' work experience most of which has been in action research and development projects in Africa and Asia, with special focus on management, commercialization and governance of natural resources. She previously worked as the East and Southern Africa Regional Coordinator for CIFOR. Phosiso holds a PhD from the University of Wales, Bangor focusing on impacts of commercialization on non-timber forest products. Email: p.sola@cgiar.org

Fergus Sinclair is Principal Scientist and Leader of the Systems Science Theme at the World Agroforestry Centre (ICRAF). He is also on the faculty in the School of the Environment, Natural Resources and Geography at Bangor University, Wales, UK and Honorary Professor at CATIE (Centre for Agricultural Research and Higher Education), Costa Rica. He has an international research career in the practical application of systems methods in agricultural and forest development, spanning more than 30 years and 40 countries. He holds a first class BSc degree in Agriculture from Reading University, England, UK and a $\mathrm{PhD}$ on the measurement and modeling of agroforestry systems from the University of Edinburgh, Scotland, UK. Email: f.sinclair@cgiar.org 


\section{List of abbreviations \& acronyms}

ACIAR Australian Centre for International Agricultural Research

CGIAR Consultative Group on International Agricultural Research

CIFOR Center for International Forestry Research

D Development

DGIS Directorate General for International Cooperation, Netherlands

DryDev Drylands Development Programme

GxE Genotype-by-Environment interaction

ICRAF World Agroforestry Centre

M\&E Monitoring and Evaluation

MeE Monitoring, structured experiential learning and Evaluation

$\mathrm{OxC} \quad$ Option-by-Context interaction

PC Planned Comparison

R Research

R4D Research for Development

RCT Randomized Control Trial

RinD Research in Development

TREES Trees for Rural Enterprise and Environment Systems

UK United Kingdom 


\section{Acknowledgements}

The ideas described have emerged from activities of several projects over the years, but most importantly the IFAD/EU-funded Dryland Restoration, ACIAR-funded Trees for Food Security and DGIS-funded DryDev projects, under the auspices of the Livelihood Systems Flagship of the CGIAR Research Programme on Forests, Trees and Agroforestry (FTA). Discussions were held with many scientists, most notably Frank Place, Leigh Winowiecki, Emilie Smith-Dumont and Edmundo Barrios. 


\begin{abstract}
Links between research and development are continuously evolving. They are becoming more important in agriculture, agroforestry and rural development as demand intensifies for large-scale transformation of livelihoods through development initiatives that are built on sound evidence. Recent research indicates that the performance of technical and social options intended to effect transformation depend on the context in which they are applied, and that those contexts vary at fine scale. This means that we rarely find simple solutions that can be scaled up to large areas and numbers of people without adaptation to local circumstances. At the same time, it is not feasible with the resources available to conduct research 'everywhere' and with 'everyone'. This puts us on the horns of a fundamental dilemma in which we need research results at scale but have conventional research approaches that are not able to provide them. We show here that this dilemma can be partially resolved by embedding research in development activity. An important method for achieving this is through use of 'planned comparisons'. Conventional monitoring and evaluation of development projects uses a retrospective approach to try to learn from what has happened in the past. We propose a more efficient prospective approach, in which comparisons of options and contexts are planned as part of development activity. Research results are generated through minor modifications to development activities rather than from distinct research work streams. This facilitates co-learning amongst researchers, development professionals and beneficiaries. Here, principles for design of planned comparisons are presented along with a generic process for implementing them.
\end{abstract}

\title{
Keywords
}

Research, development, scaling up, experimental design, planned comparison 


\section{Aims}

The idea of 'planned comparisons' (PCs) has been introduced and used in several ICRAF projects that have adopted an RinD (Research-in-Development) approach (Coe et al., 2014). There are many different interpretations of the concept among people working in these projects and those planning new ones. Scientific progress depends on diversity of opinion and on diverse application of concepts, principles and methods. However, it is also important to have a common understanding of what we mean when using a shorthand such as 'PC' 1 . This paper provides a description of the concept and resulting methods, the reasons it was developed and its links with other ideas in research for development (R4D). The aim is to provide a succinct description of the core ideas as a basis for that common understanding. A diversity of applications and further concepts can then be developed from this base. These ideas have emerged from experience with research and development in agriculture, agroforestry and rural land use and so are described here in that context but have application in other domains.

\section{Definitions}

Throughout the text these key terms are used with the following specific meanings:

Options are the things that farmers, communities, extension agents or others engaged in development activities can choose to do differently. Many development projects work by bringing new options to farmers and others - new varieties, new land use practices, new technology. They may also suggest change to institutional or organizational structures, market interventions, policies or new options for transferring knowledge. The use of 'option' as a collective term for these innovations emphasizes that there are many different alternatives and that people exercise choice in whether or not to adopt them.

Contexts are the specific situations in which options are introduced. Ecological, economic and social dimensions of context are usually important and may be defined at any scale appropriate to, where and for whom, change is being considered. The soil depth in a specific field or a national policy may be important dimensions of context. Much research has been done on describing contexts and developing tools to do so. In the case of social contexts, wealth ranking (Grandin, 1988) and construction of farmer typologies (Alvarez \& Tittonell, 2014) are well known examples.

Responses are the measureable results of using different options. They are the changes in variables that people care about and wanted to change by introducing new options. They can be measured quantitatively (such as crop yield, tree cover, or level of group membership) or qualitatively (such as preferences for different tree species or enthusiasm for collective action).

\footnotetext{
${ }^{1}$ The working title of this document was "PCRECPC", that is "PCs (planned comparisons) are easy peasy". We hope they will be after going through the document.
} 


\section{TREES - a development project supporting tree planting}

This example of a typical development project will be used for illustration throughout the paper. This generic project is similar to many being put in place in different countries but is not modelled on an actual project.

The project area is densely populated with small-scale farmers. The landscape has low tree cover. There is no strong tradition of tree planting because until recently farmers had access to forest resources. Studies in the area suggest that introducing tree planting and appropriate management practices would help meet farmers' needs for tree products, provide new income streams and help address some local environmental concerns. Hence the project "Trees for rural enterprise and environment systems" (TREES) was designed and funded.

The project aims to reach at least 20,000 farms spread over an area of $15,000 \mathrm{~km}^{2}$. It is implemented by a consortium of government and nongovernment development agencies that already work on other rural development initiatives in the same area.

Project activities include:

- Providing tree seed

- Training farmers in tree growing and management

- Establishing community nurseries

- Helping with marketing of tree products

\section{The core problem: research, development and the connections}

Very generally, in our business of natural resource management, agriculture and rural development, the role of research $(\mathrm{R})$ is to use scientific methods to understand how systems are working and their problems. We then use that knowledge to develop potential solutions to problems or changes that will make the system work better, which we refer to as options. These options can be either technical or social. 'Development' means systems changing, for the better, as defined by someone's point of view usually that of the people who are 'developing' or those who are funding the development. Development actions or interventions (D) are designed to promote and facilitate the uptake of options. These actions include providing information, access to materials or finance, strengthening institutions, adjusting policies and so on.

The relationships between $\mathrm{R}$ and $\mathrm{D}$ have been much studied and continue to evolve. For many years the dominant model was one of 'technology transfer' in which $\mathrm{R}$ developed options, usually of a technical nature. Researchers then handed them over to development agencies for delivery to farmers and scaling-up (or -out), meaning making them available to ever more people or areas. Recently, this model has been challenged for a number of reasons. These include: 
- Funding for R coming from development budgets with donors interested primarily in impact, and not research outputs.

- Adoption of participatory principles that require beneficiaries of $\mathrm{R}$ to be part of the research process.

- An increased feeling of urgency and a need to take action on problems now, and not later.

In addition, there are two common observations about much of what we do that are so pervasive they might be taken as empirical laws. They should be having a profound effect on the relation between $\mathrm{R}$ and $\mathrm{D}$. These are:

1. Contexts vary a lot and do so at a fine scale. There is important and relevant ecological, social and economic variation even at fine scales. In the domains in which we work, soils, farmer attitudes, access to credit and many other factors vary greatly.

2. There are often option-by-context interactions. The response to an option in one context may not be the same in another.

The concept of option-by-context interactions $(\mathrm{OxC})$ has been around for a long time. Crop breeders, for example, have recognized genotype by environment interactions (GxE) and developed tools to understand them and approaches to exploiting them (Annicchiarico, 2002). The general implication is that there are few 'silver bullet' options that are going to be appropriate for large numbers of people and over large areas (Coe et al., 2014; Nelson \& Coe, 2014). Options need developing for, or adapting to, local and varying situations.

Hence we have the core problem being addressed here:

The world needs and expects solutions to problems and options that will bring benefits at scale. However, conventional research often delivers results that are only relevant to the locations, environments and people where they were developed. How can D move ahead to support change when $R$ has not delivered all the knowledge apparently needed? 


\section{TREES - options and contexts}

The Forest Department has been providing seedlings for farmers to plant woodlots of eucalyptus and grevillea and they seem to grow fast. Hence the project initially planned to distribute these two species. Researchers and conservationists proposed that a greater diversity of species be offered. However, there was no information on basic management techniques for many of these. Further, the project hoped to show farmers that, beyond woodlots, many other niches and planting arrangements could be used, but recommended practices had only been investigated at a research station on the edge of the project area.

A social scientist raised a concern that distributing seedlings is not sustainable and communities should be supported to run their own nurseries. But there was disagreement over the relative merits of community-run and small commercial nurseries.

Hence the project planners had the problem of needing to promote tree seedling production and planting, but not having all the necessary knowledge, neither social and economic (approaches for sustainable seedling production) nor biophysical (species, niches and management).

\section{Conventional solutions to the core problem}

The core problem of providing enough research-based information to support development actions in diverse environments has long been faced. There are three conventional solutions summarized in Table 1.

Table 1: Conventional solutions to the core problem

\begin{tabular}{|c|c|c|}
\hline Solution & When used & Risk \\
\hline $\begin{array}{l}\text { 1. Continue the research, } \\
\text { repeating in new contexts }\end{array}$ & $\begin{array}{l}\text { Researchers' default } \\
\text { approach }\end{array}$ & $\begin{array}{l}\text { We never know enough to move } \\
\text { to scale and researchers lose } \\
\text { credibility }\end{array}$ \\
\hline $\begin{array}{l}\text { 2. Use broad } \\
\text { recommendations and hope } \\
\text { they are good enough }\end{array}$ & $\begin{array}{l}\text { The approach often used by } \\
\text { governments and large } \\
\text { development initiatives }\end{array}$ & $\begin{array}{l}\text { Low return on farmer investment } \\
\text { Farmers lose confidence } \\
\text { Opportunity costs for all involved } \\
\text { Development agencies and } \\
\text { researchers lose credibility }\end{array}$ \\
\hline $\begin{array}{l}\text { 3. Assume farmers will make } \\
\text { local adaptations to fill gaps }\end{array}$ & $\begin{array}{l}\text { Often used by initiatives } \\
\text { with a strong social focus }\end{array}$ & $\begin{array}{l}\text { Inefficient and slow } \\
\text { Ignores relevant knowledge }\end{array}$ \\
\hline
\end{tabular}

There are, of course, overlaps and many variations to the approaches listed in Table 1. Each of these has a role and there may be situations in which they are appropriate and steps that can be taken to reduce the risks.

An important variant of Solution 3 is for development agents to provide knowledge of principles that are widely applicable, leaving farmers to find ways of using the principles in a 
way that work for them. An example is teaching farmers the principles of nitrogen fixation and nutrient cycling while leaving them to identify the crops and trees that allow them to exploit these phenomena, rather than giving specific recommendations. But that is also likely to have the same risks as Solution 3 in Table 1.

\section{TREES - addressing the core problem}

The three approaches of Table 1 would involve the following:

1. Continued research: persuade donors to spend the first few years conducting trials on species $\mathrm{x}$ niche interactions, adoption potential and the costs and benefits of alternative nursery models. Move to scale after five years of research.

2. Broad recommendations: take species information from international databases and management recommendations (e.g. spacing) from trials done elsewhere in the region. Select community nurseries due to their success in another country.

3. Farmers' adaptation: deliver a range of tree species and leave farmers to choose.

When Solution 2 is used, then some initiatives try to learn what is working where through using data collected as part of monitoring or evaluation (M\&E). M\&E data are often superficial and aimed at reporting and justifying activities rather than evidence-based learning. However, some initiatives collect sufficiently detailed data (both qualitative and quantitative) with the aim of analysis and interpretation to refine recommendations or make them more specific. For example, if farmers find that planting species $\mathrm{A}$ in niche $\mathrm{X}$ is successful, but for niche $\mathrm{Y}$ then species $\mathrm{B}$ is better, that could become part of a future recommendation. The risks of this approach include the fact that it is slow. But there are often more fundamental problems.

Table 2: Comparing options (species) in two contexts (niches)

\begin{tabular}{|c|c|c|}
\hline & \multicolumn{2}{|c|}{ Species } \\
\hline Niche & A & B \\
\hline X & + & - \\
\hline Y & - & + \\
\hline
\end{tabular}

Table 2 shows the simplest sort of data resulting from such M\&E. The performance (on whatever criteria matter to you) for each combination of options and contexts is recorded. It is summarized for each cell in the table (four in this case) in an appropriate way, represented here by ' + ' and ' - '. So the interpretation of Table 2 is that when comparing species A and B, A performs better in one niche and B in the other. However there are two common problems with this approach:

1. There may be few data points for some of the cells.

2. There are confounding factors, so that the difference between farmers who planted A and those who planted B is not just the species, but something else as well. 
Both these problems are likely to become more serious with more realistic data which has more options, more contexts and more dimensions of context (other than just 'niche'). Notice that interpretation of this sort of data always requires comparisons - comparisons between options, between contexts and combinations of these. As described here, the comparisons were not planned at the time the M\&E was set up. The comparisons are unplanned and the approach is retrospective. The project does whatever it does to promote and support farmers use of options, collects the data and only then tries to make the comparisons.

The PC concept takes elements of all three of these solutions and combines them in ways that reduce the risks of each, as elaborated in the next section.

\section{Planned comparisons}

Planned comparisons fit into a broader research in development (RinD) approach that embeds research within development praxis to accelerate co-learning and development impact (Figure 1).

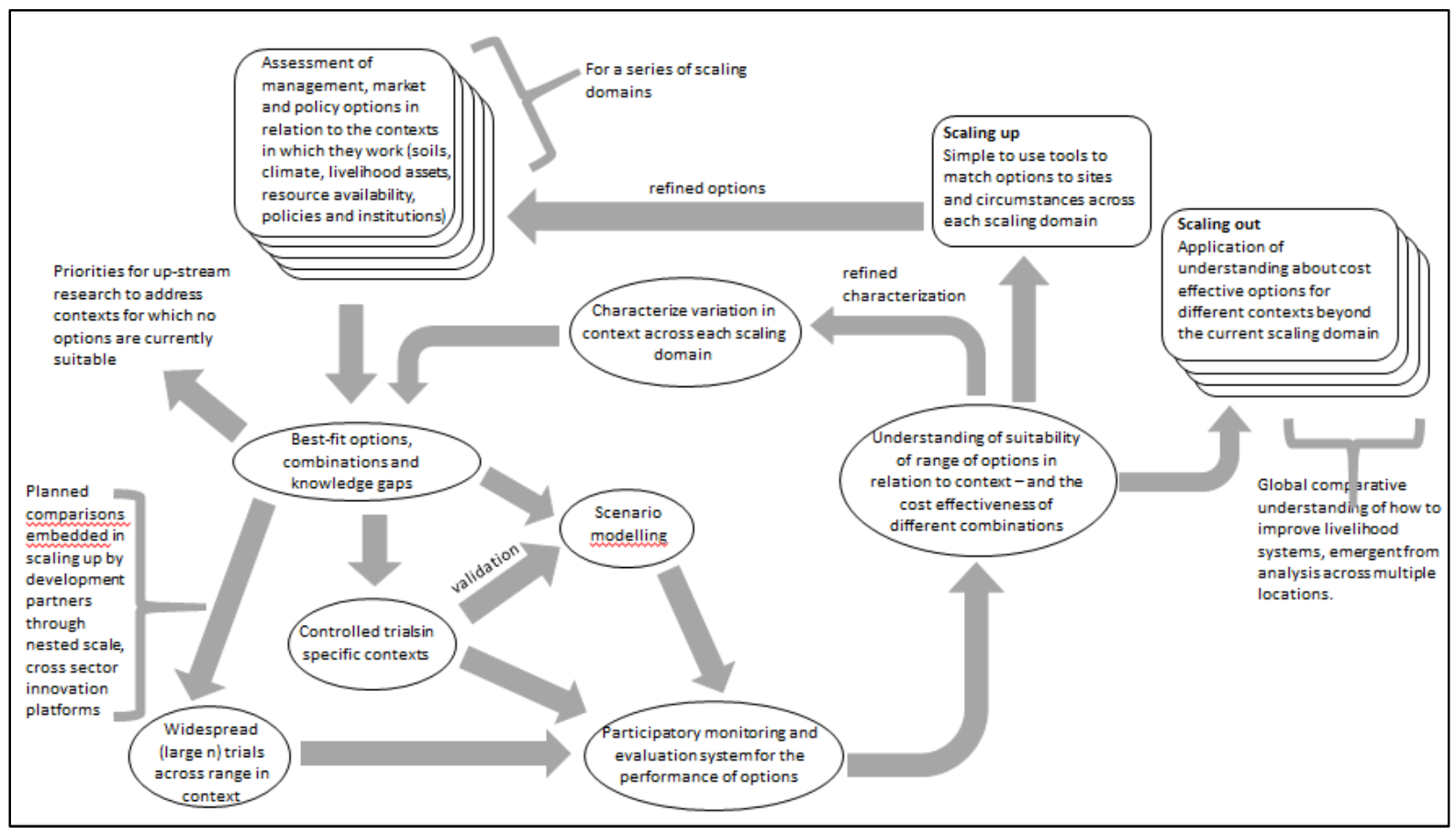

Figure 1: The $R$ in D approach, with the role of PCs highlighted (adapted from Coe et al 2014)

The core idea is that farmers and those supporting them (the development agents and their funders) are looking for options now, not after yet more research. So we suggest 'good bets' or 'best fit'- options that, based on all available knowledge, including local knowledge, we predict will be useful to farmers. At the same time, we are explicit about the key areas of uncertainty in relation to addressing the issue or challenge in question, in general and in different contexts in particular. Then we set up mechanisms for addressing this uncertainty through continually learning, thereby refining and updating the options being suggested and promoted. 
However, the standard approaches to such learning are retrospective (try something, wait to see what happens, reflect on the outcome and try something different). The problems with that approach were outlined in the previous section. They can be overcome by planning the comparisons that will be made between options and between contexts, and making sure the design will give good information on them, rather than leaving it to chance. This is the essence of the PC idea and the origin of the name.

To take the example from Table 2, the planned comparison design is simple. Farmers plant both species $\mathrm{A}$ and $\mathrm{B}$. If a farmer has both niche $\mathrm{X}$ and niche $\mathrm{Y}$ on their farm (e.g. homestead and field boundary) then they can also plant both A and B in both niches. This takes care of most of the confounding problems and others can be reduced by making sure farmers understand the importance of 'like with like' comparison and applying a few other design principles outlined below. Achieving adequate sample size is something the project managers can build into their planning. The difference between the conventional and PC approach for this example is summarized in Table 3.

Table 3: Planned comparison (PC) approach to generating data for Table 2

\begin{tabular}{|ll|}
\hline Conventional approach & PC approach \\
\hline Farmers given information & Farmers given information \\
and seeds to encourage & and seeds to encourage \\
planting of trees, choosing & planting of trees, choosing \\
species and niches. & species and niches. \\
& They are required to plant at \\
& least 2 different species in \\
& each niche and/or plant the \\
& same species in at least 2 \\
& niches. \\
\hline
\end{tabular}

The difference between the two approaches is very slight in operational terms, but can be very important in terms of how information is generated and the potential for learning. For the case summarized in Table 3, the difference it makes to a farmer could be no more than a rule 'If you want to take part in this project then you agree to plant at least two different species or plant in two different niches'. This is something that can be justified in terms of promoting diversity, irrespective of the PC concept. 
Table 4: PCs as a combination of other approaches

\begin{tabular}{|l|ll|}
\hline $\begin{array}{l}\text { Solution } \\
\text { 1. Continue the research, } \\
\text { repeating in new contexts }\end{array}$ & $\begin{array}{l}\text { PC approach } \\
\text { The research continues, but } \\
\text { as part of the development } \\
\text { process rather than } \\
\text { something separate from it }\end{array}$ & $\begin{array}{l}\text { Advantages } \\
\text { Allows continued increase in } \\
\text { understanding and contribution to } \\
\text { both local and global knowledge } \\
\text { bases while also bringing options } \\
\text { to farmers at scale }\end{array}$ \\
\hline $\begin{array}{l}\text { 2. Use broad } \\
\text { recommendations and hope } \\
\text { they are good enough }\end{array}$ & $\begin{array}{l}\text { Acknowledge that the broad } \\
\text { recommendations are only } \\
\text { the start, that there is much } \\
\text { we do not know, but R has } \\
\text { sufficient information for } \\
\text { farmers to try some } \\
\text { alternatives }\end{array}$ & $\begin{array}{l}\text { Realistic regarding both R and D } \\
\text { components } \\
\text { Not based on 'hope' but on } \\
\text { scientific approaches }\end{array}$ \\
\hline $\begin{array}{l}\text { 3. Assume farmers will make } \\
\text { local adaptations that fill gaps }\end{array}$ & $\begin{array}{l}\text { Work with farmers to } \\
\text { develop the adaptations and } \\
\text { alternatives to be tested, } \\
\text { ensuring they are based on } \\
\text { the best available } \\
\text { understanding }\end{array}$ & $\begin{array}{l}\text { A planned, systematic and } \\
\text { informed approach, rather than } \\
\text { one based on assumptions that } \\
\text { farmers will do it }\end{array}$ \\
\hline
\end{tabular}

If we look at Table 1 again and the conventional approaches, R in D and PCs can be seen as taking elements of each of them but reducing the risks (Table 4). There are still risks but many are clearly mitigated.

\section{TREES - using a PC approach}

Two planned comparisons were designed:

1. Understanding tree species by niche interactions. 20 species for on-farm planting were identified from local and scientific knowledge (see methods for how do this in Smith-Dumont et al., 2017). Five different on-farm niches for tree planting identified through participatory landscape assessment (woodlots, field boundaries, scattered in cropland, stream banks, home-gardens). Performance (survival, early growth, farmers' appreciation) assessed for realistic niche by species combinations by having farmers plant multiple species and niches.

2. Routes to sustainable nurseries. Villages in the project area divided into two groups. In one group the project will support development of community nurseries. In the other the project will support development of small commercial nurseries. 


\section{PC designs, principles and process}

PCs in development projects can be of very diverse designs. As in any research, the details of the design will depend on the specific objectives and there is endless variety in those.

However, we can identify some principles for design of PCs and processes for putting them into practice. These are described below. Before that, some examples are described, to help motivate and illustrate the principles.

\section{Designs}

Table 5 outlines several examples of PCs that are designed in different ways. The most common and easiest to understand are those in which each farmer compares several different options, each on a different plot. These can look very like conventional on-farm trials, and in terms of the logic of how information is generated they are. However, they are very different in terms of how they are introduced and explained to farmers. If we take the example of comparing performance of different tree species, the traditional on-farm trial would involve a pitch to farmers along the lines of:

"We are interested in comparing these species. Are you interested in joining? We will provide access to the trees and some training. You will need to plant and care for the trees. At the end of the trial they are your trees."

When the PC is embedded in a development project, the pitch to farmers is more like:

"In this project we are supporting farmers in planting trees. Are you interested in joining in? We will provide access to the trees and some training. If you want to join in then you will need to plant at least two different species and share your experience of them with us."

Note that only the sentence in bold is different from what would happen in a development project with no built-in PCs. From the perspective of farmers, the activity is not research, an experiment or trial. It is support for tree planting. They are choosing to take part in a project and one of the conditions is that they try a diversity of options, not just one.

Table 5: Examples of types of PC designs

\begin{tabular}{|c|c|c|c|}
\hline Design type & Characteristics & $\begin{array}{l}\text { Examples of } \\
\text { comparisons }\end{array}$ & $\begin{array}{l}\text { Advantages and } \\
\text { disadvantages }\end{array}$ \\
\hline Within farm & $\begin{array}{l}\text { Different options } \\
\text { compared on } \\
\text { different plots or } \\
\text { fields within the } \\
\text { same farm. Many } \\
\text { farms involved }\end{array}$ & $\begin{array}{l}\text { Tree species } \\
\text { Tree and crop } \\
\text { management } \\
\text { Niche within farm }\end{array}$ & $\begin{array}{l}\text { The simplest to organize } \\
\text { and understand } \\
\text { Gives information } \\
\text { directly relevant to each } \\
\text { farmer, as well as } \\
\text { information from } \\
\text { compiled results } \\
\text { Most precise } \\
\text { comparisons of options } \\
\text { because unrecognized } \\
\text { farm-to-farm variation } \\
\text { has less effect on results }\end{array}$ \\
\hline $\begin{array}{l}\text { Between } \\
\text { farms or } \\
\text { households }\end{array}$ & $\begin{array}{l}\text { Different options } \\
\text { compared on } \\
\text { different farms or }\end{array}$ & $\begin{array}{l}\text { Landscape positions } \\
\text { Farmer types (e.g. wealth } \\
\text { groups) }\end{array}$ & $\begin{array}{l}\text { Use when each farm can } \\
\text { try only a single option } \\
\text { and represents only one }\end{array}$ \\
\hline
\end{tabular}




\begin{tabular}{|llll|}
\hline Design type & $\begin{array}{l}\text { Characteristics } \\
\text { households within } \\
\text { the same 'zone'. } \\
\begin{array}{l}\text { Many farms } \\
\text { involved }\end{array}\end{array}$ & $\begin{array}{l}\text { Examples of } \\
\text { comparisons }\end{array}$ & $\begin{array}{l}\text { Advantages and } \\
\text { disadvantages }\end{array}$ \\
\hline & & $\begin{array}{l}\text { context } \\
\text { Requires data to be } \\
\text { compiled across farms } \\
\text { before it makes sense }\end{array}$ \\
& & $\begin{array}{l}\text { Farm-to-farm variation } \\
\text { influences results so } \\
\text { design may have low } \\
\text { precision }\end{array}$ \\
\hline $\begin{array}{l}\text { Between } \\
\text { communities }\end{array}$ & $\begin{array}{l}\text { Different options } \\
\text { compared between } \\
\text { different } \\
\text { communities Many } \\
\text { communities } \\
\text { involved. Each may } \\
\text { have many or few } \\
\text { participants }\end{array}$ & $\begin{array}{l}\text { Training or extension } \\
\text { method }\end{array}$ & $\begin{array}{l}\text { Use when the options are } \\
\text { applied to distinct groups } \\
\text { of people or communities }\end{array}$ \\
action stimulating group & Seed supply methods & $\begin{array}{l}\text { Usually relevant for } \\
\text { comparison of social } \\
\text { innovation options. }\end{array}$ \\
\hline
\end{tabular}

The second and third rows of Table 5 outline PCs that can be designed when the options are relevant to whole farms or larger units - such as watersheds, communities or local government jurisdictions.

The range of possible designs that the PC idea spans is illustrated by diverse approaches to the 'Within farm' designs of Table 5. If the options to compare are tree species then possible schemes for determining which species are compared on each farm include:

- All farmers testing all the species.

- Each farmer selecting the subset of species they want to test from all those on offer..

- Farmers selecting the subset of species to test within some rules such as '...must include at least one legume and one tree species you have never grown before...'.

- Designers allocating a subset to test on each farm, selected so that all combinations are tested over the whole PC.

- Letting farmers choose from a limited number of combinations of species each of which has been designed as a balanced portfolio.

- Group-level selection in which farmers in one group or community collectively decide on the subset of species they will each test.

Each of these has different properties and will be appropriate for different objectives and situations.

\section{Principles}

The principles of PC design are:

1. Use the concepts of experimental design (treatment comparison, randomization, variation control), that are relevant whatever the size of the study and whether responses are qualitative or quantitative.

2. Recognize and allow for the flexibility and choice that should be part of any development project. 
3. Aim for minimal disturbance to the project process that would have been used if there were no PCs.

4. Ensure the comparisons make sense to and provide useful information to those who are making them, not just to researchers and development agents. When intra-farm comparisons are made, they should be interpretable and informative to the individual farmers involved, as well as collectively when data are assembled.

5. Plan PCs as a core part of the development project rather than an add-on activity.

\section{Process}

The actual process for designing PCs will depend on many aspects of the development initiative within which they are integrated, including farmer and other stakeholder participation (next section). They should be planned as part of the whole initiative and integrated with other activities. Steps for designing a PC are outlined below. In practice, these will be embedded in a more comprehensive planning process, which will include priority setting.

1. Determine the objectives of the PC. This will be based on dialogue and multiple information sources. Objectives should be based on filling information gaps that are restricting the viability of the development initiative or adding to farmer uncertainty and risk, so a process of identifying these gaps will need to be part of the design. Objectives will often be based on hypotheses about option by context interactions.

2. Choose an overall approach (Table 5) and ensure it is viable and acceptable to all involved.

3. Decide on details of core elements of the design. These are:

- Options to compare

- Contexts in which they will be compared (not all options need be compared across all contexts)

- The study units (fields, farms, communities, etc.)

- The responses to be measured. These can include quantitative and qualitative responses (e.g. acceptability)

- The roles of farmers and others

- Resources needed, including human resources for data collection and analysis.

4. Review the design and ensure that it is viable.

5. Complete the plan with further details.

\section{PCs and participation}

'Participation' of farmers, extension agents and others in development initiatives takes many different forms and is predicated on different reasons including:

- It is a value of those involved in project conception and design and a right of farmers and communities to influence things done on their behalf.

- It is deemed necessary if farmers and communities are to be inspired to take part in activities and sustain efforts beyond the project. 
- It is deemed necessary for adapting activities to local conditions.

The PC concept is neutral with regard to participation. It can be relevant whatever styles of participation are implemented in different stages of a development initiative. Successful PCs have involved farmer participation in different ways, for example:

- Participatory action planning was used to identify learning priorities. Project staff then designed PCs that would address those priorities for which they were best suited.

- A participatory design process that combined farmer and scientific knowledge was used to choose both objectives and details of the PC.

- Project staff designed the PC but in such a way that farmers themselves choose the options they would compare on their farm.

Effective links between research and action depend on paying attention to credibility, salience and legitimacy (Cash et al., 2003). PCs can contribute to each of these, but the concept is not sufficient to meet the needs of any of them. Other processes, including those that determine the style of participation, are needed.

\section{PCs and other modes of learning and research within development initiatives}

Development initiatives can take multiple approaches to learning and research. PCs are one of these, but do not exclude or replace others. There will, inevitably, be questions that arise that will be more appropriately addressed by other approaches. These approaches include:

- Conventional (retrospective) evaluation, involving any of the stakeholders. This is particularly appropriate for discovering aspect of the contexts, options and their interactions that were not anticipated during project planning.

- Conventional research (experimental or observational, more or less participatory) added as a separate stream of activity. This will be needed when the questions will not give answers immediately of value to farmers, or require activities that are distinctly different from the 'promotion of options' work of development.

- Using models, perhaps as a participatory exercise, to generate predictions and explore scenarios before farmers start trying any options.

- Planned or unplanned impact assessments to assess the overall effectiveness or costeffectiveness of the development project. This may be coupled with the use of mixed methods to interrogate how and why the project did or did not achieve its expected impacts

Many development initiatives will have more questions than can be addressed through PCs. In principle there is no limit to the number of PCs that can be included in one initiative, or that a single farmer can be involved in. But in practice, it will be difficult to keep track of aims, implementation, data collection and use if there are too many overlapping PCs. Hence other ways of learning may be needed, even when questions could be addressed by PCs. Some priority setting will be needed for which PCs are taken forward at any point in time. 
Criteria for selecting priorities are:

1. The principles of PC design ( above) can be applied.

2. Progress is currently limited by lack of information

3. Answers will give actionable information that will make a difference to what farmers or others are doing.

It is the responsibility of designers and managers of development initiatives to find the learning and research modes that meet their needs, combining PCs with other approaches. When embedded in a broader RinD approach, the intention is to set up an iterative cycle involving key research, development, client (farmers) and private sector actors that may persist beyond the life of any specific initiative because it is useful for the actors involved.

\section{Links to alternatives and the calling of names}

The concept of planned comparisons described here is not new and is closely linked to other ideas and paradigms used in research, development and action. For example, action research (Kemmis et al., 2014) often involves 'doing something', assessing it, updating the design and trying again. Perhaps there are two distinctions from the PC approach. The first is that in action research the aim is often to solve a local problem, while PCs aim to contribute to that at the same time as providing global knowledge (see Figure 1). The second is the concept of comparing options in parallel rather than sequentially. The idea of randomized control trials (RCTs) to evaluate development interventions is becoming more widely used (Duflo et al., 2008, Ferraro, 2011) and criticized (Barrett \& Carter, 2010). These designs are often similar to the between-community designs (Table 5) outlined above. If there are distinctions from PCs, it is that these RCTs are typically designed to evaluate the effect or impact of an intervention, and often involve a comparison of intervention versus none or business as usual. PCs are focused on developing knowledge that is needed to make the most of options and so will often focus on questions other than 'What is the difference between having the intervention and business as usual?'. Pritchett et al., (2013) propose an approach labelled $\mathrm{MeE}$, with structured experiential learning (or experimentation) added to more conventional M\&E designs. This effectively includes the PC concept.

Table 6: Proposed alternative names for the PC concept

\begin{tabular}{|ll|}
\hline $\begin{array}{l}\text { Proposed name } \\
\text { Scale-up learning through } \\
\text { comparions and contexts }\end{array}$ & $\begin{array}{l}\text { Comments } \\
\text { lead to scaling-up. They will not. }\end{array}$ \\
\hline Farmer field scaling & $\begin{array}{l}\text { Describes the whole process of implementing PCs rather } \\
\text { than just the PCs themselves. Indicates building on the } \\
\text { farmer field school approach but connecting up across } \\
\text { large networks through nested-scale innovation platforms. }\end{array}$ \\
\hline Large farm trials & $\begin{array}{l}\text { Misses the notion of the trial being part of a development } \\
\text { or scaling activity. Trials involving many farmers are } \\
\text { something researchers have organized for a long time. }\end{array}$ \\
\hline Option comparison at scale & $\begin{array}{l}\text { This is also what the traditional retrospective M+E } \\
\text { process tries to do. The novel element of planning the } \\
\text { comparison using experimental design principles is } \\
\text { missed. }\end{array}$ \\
\hline
\end{tabular}




\begin{tabular}{|c|c|}
\hline Proposed name & Comments \\
\hline $\begin{array}{l}\text { Development Option } \\
\text { Comparison }\end{array}$ & $\begin{array}{l}\text { This is also what the tradition retrospective } \mathrm{M}+\mathrm{E} \text { process } \\
\text { tries to do. The novel element of planning the comparison } \\
\text { using experimental design principles is missed. }\end{array}$ \\
\hline $\begin{array}{l}\text { Development Option } \\
\text { Comparison at Scale }\end{array}$ & $\begin{array}{l}\text { This is also what the tradition retrospective } \mathrm{M}+\mathrm{E} \text { process } \\
\text { tries to do. The novel element of planning the comparison } \\
\text { using experimental design principles is missed. }\end{array}$ \\
\hline Embedded comparisons & $\begin{array}{l}\text { This is close, but could also describe the unplanned } \\
\text { conventional } \mathrm{M}+\mathrm{E} \text { approach }\end{array}$ \\
\hline Participatory learning models & $\begin{array}{l}\text { There are many of these. PCs just contribute one element } \\
\text { of participatory learning. }\end{array}$ \\
\hline Farmer Learning Trials & $\begin{array}{l}\text { The learning is not only for farmers. FLTs might also } \\
\text { describe farmer field school type trials. }\end{array}$ \\
\hline $\begin{array}{l}\text { Participatory farmer action } \\
\text { learning }\end{array}$ & There are many of these. PCs just contribute one element \\
\hline Scaling Options to Contexts & This does not capture the idea of continued research. \\
\hline $\begin{array}{l}\text { Farmer-Designed Farmer- } \\
\text { Managed Experiments }\end{array}$ & $\begin{array}{l}\text { These have been around for a long time as part of } \\
\text { 'participatory technology development' but not as part of } \\
\text { development projects. They can be done as R in the } \\
\text { absence of D and moving to scale. }\end{array}$ \\
\hline Participatory Trials & $\begin{array}{l}\text { There are many different styles and purposes of these and } \\
\text { the name does not distinguish the special characteristics } \\
\text { of PCs. }\end{array}$ \\
\hline R4D Partners Learning & $\begin{array}{l}\text { There are many approaches. PCs just contribute one } \\
\text { element. }\end{array}$ \\
\hline Last Mile Trials & $\begin{array}{l}\text { PCs are not only concerned with the final part of reaching } \\
\text { farmers but also generate more widely useful knowledge. }\end{array}$ \\
\hline
\end{tabular}

Likewise, there are overlaps with many other approaches. For example:

- Farmer field schools (Braun et al., 2006) are based on the idea of farmers collectively conducting experiments to learn about processes and what works.

- The broad area labelled "participatory technology development" includes multiple models for farmers engaging in research (Neef \& Neubert, 2011).

However, the genesis and principles of PCs, described in earlier sections, are novel and enrich the set of concepts, approaches and methods available.

We have been told that the term 'planned comparisons' or 'PCs' is obscure and does not help people understand it or its relevance. Alternative names have been proposed (Table 6). All of these names have some elements that are indeed relevant to what PCs are trying to do. However, most also have other implications or limitations, are already used for other concepts or describe the whole RinD approach rather than just the PC part. The 'planned comparison' term has its drawbacks, but the alternatives tabled so far have not found sufficient traction to replace it. It is perhaps more important to describe what is done and why, as we have done here, rather than to worry too much about what name we use as label for it. 


\section{References}

Alvarez, S. \& Tittonell, P. (2014). Typology construction, a way of dealing with farm diversity: General guidelines for humidtropics (December): 0-36.

Annicchiarico, P. (2002). Genotype x Environment interactions - challenges and opportunities for plant breeding and cultivar recommendations. Rome: FAO. Retrieved from http://www.fao.org/DOCREP/005/Y4391E/Y4391E00.HTM\#Contents

Barrett, C.B. \& Carter, M.R. (2010). The power and pitfalls of experiments in development economics: Some non-random reflections. Applied Economic Perspectives and Policy 32(4): 515-548. Retrieved from http://aepp.oxfordjournals.org/lookup/doi/10.1093/aepp/ppq023

Braun, A., Jiggins, J., Röling, N. \& van den Berg, H. (2006). A global survey and review of farmer field school experiences. Nairobi: International Livestock Research Insitute.

Cash, D.W., Clark, W.C., Alcock, F., Dickson, N.M., Eckley, N., Guston, D.H., ... Mitchell, R.B. (2003). Knowledge systems for sustainable development. Proceedings of the National Academy of Sciences of the United States of America 100(14): 8086-8091.

Coe, R., Sinclair, F. \& Barrios, E. (2014). Scaling up agroforestry requires research 'in' rather than 'for' development. Current Opinion in Environmental Sustainability 6: 7377.

Duflo, E., Glennerster, R. \& Kremer, M. (2008). Using randomization in development economics research : A toolkit. In Handbook of Development Economics, Vol 4 (Vol. 4). Elsevier B.V.

Ferraro, P.J. (2011). Experimental project designs in the Global Environment Facility: Designing projects to create evidence and catalyze investments to secure global environmental benefits. A STAP advisory document October 2011.

Grandin, B. (1988). Wealth ranking in smallholder communities: a field manual. Rugby: Intermediate Technology Publications.

Kemmis, S., Mctaggart, R. \& Nixon, R. (2014). The action research planner. Springer.

Neef, A. \& Neubert, D. (2011). Stakeholder participation in agricultural research projects: A conceptual framework for reflection and decision-making. Agriculture and Human Values 28: 179-194.

Nelson, R. \& Coe, R. (2014). Transforming research and development practice to support agroecological intensification of smallholder farming. Journal of International Affairs 67(2): 107-127.

Pritchett, L., Salimah, S. \& Hammer, J. (2013). It's all about MeE: Using structured experiential learning to crawl the design space (April 2013).

Smith-Dumont, E., Bonhomme, S., Pagella, T. \& Sinclair, F.L. (2017). Structured stakeholder engagement leads to development of more diverse and inclusive agroforestry options. Experimental Agriculture 1-23. 


\section{Working Paper series}

240. The national agroforestry policy of India: experiential learning in development and delivery phases. http://dx.doi.org/10.5716/WP16143.PDF

241. Agroforestry and forestry in Sulawesi series: Livelihood strategies and land-use system dynamics in Gorontalo. http://dx.doi.org/10.5716/WP16157.PDF

242. Seri Agroforestri dan Kehutanan di Sulawesi: Strategi mata pencaharian dan dinamika sistem penggunaan lahan di Gorontalo. http://dx.doi.org/10.5716/WP16158.PDF

243. Ruang, Gender dan Kualitas Hidup Manusia: Sebuah studi Gender pada komunitas perantau dan pengelola kebun di Jawa Barat. http://dx.doi.org/10.5716/WP16159.PDF

244. Gendered knowledge and perception in managing grassland areas in East Sumba, Indonesia. http://dx.doi.org/10.5716/WP16160.PDF

245. Pengetahuan dan persepsi masyarakat pengelola padang aavana, Sebuah Kajian Gender di Sumba Timur. http://dx.doi.org/10.5716/WP16161.PDF

246. Dinamika Pengambilan Keputusan pada komunitas perantau dan pengelola kebun di Jawa Barat. http://dx.doi.org/10.5716/WP16162.PDF

247. Gaharu (eaglewood) domestication: biotechnology, markets and agroforestry options. http://dx.doi.org/10.5716/WP16163.PDF

248. Marine habitats of the Lamu-Kiunga coast: an assessment of biodiversity value, threats and opportunities. http://dx.doi.org/10.5716/WP16167.PDF

249. Assessment of the biodiversity in terrestrial landscapes of the Witu protected area and surroundings, Lamu County Kenya. http://dx.doi.org/10.5716/WP16172.PDF

250. An ecosystem services perspective on benefits that people derive from biodiversity of Coastal forests in Lamu County, Kenya http://dx.doi.org/10.5716/WP16173.PDF

251. Assessment of the biodiversity in terrestrial and marine landscapes of the proposed Laga Badana National Park and surrounding areas, Jubaland, Somalia. http://dx.doi.org/10.5716/WP16174.PDF

252. Preferensi Petani terhadap Topik Penyuluhan dan Penyebaran Informasi Agroforestri di Indonesia http://dx.doi.org/10.5716/WP16181.PDF

253. Seri Agroforestri dan Kehutanan di Sulawesi: Keanekaragaman hayati jenis pohon pada hutan rakyat agroforestri di DAS Balangtieng, Sulawesi Selatan http://dx.doi.org/10.5716/WP16182.PDF

254. Potensi dan Tantangan dalam Pengembangan Skema Ko-Investasi Jasa Lingkungan di Kabupaten Buol, Indonesia. http://dx.doi.org/10.5716/WP17008.PDF

255. Keragaman Jenis Pohon dan Pemanfaatannya oleh Masyarakat di Kabupaten Buol, Indonesia. http://dx.doi.org/10.5716/WP17009.PDF

256. Kerentanan dan preferensi sistem pertanian petani di Kabupaten Buol, Indonesia http://dx.doi.org/10.5716/WP17010.PDF

257. Dinamika Perubahan Penggunaan/Tutupan Lahan Serta Cadangan Karbon di Kabupaten Buol, Indonesia. http://dx.doi.org/10.5716/WP17011.PDF

258. The effectiveness of the volunteer farmer trainer approach vis-à-vis other information sources in dissemination of livestock feed technologies in Uganda. http://dx.doi.org/10.5716/WP17104.PDF

259. Agroforestry and forestry in Sulawesi series: Impact of agricultural-extension booklets on community livelihoods in South and Southeast Sulawesi.

http://dx.doi.org/10.5716/WP17125.PDF

260. Petani Menjadi Penyuluh, Mungkinkah? Sebuah Pendekatan Penyuluhan dari Petani ke Petani di Kabupaten Sumba Timur. http://dx.doi.org/10.5716/WP17145.PDF

261. Dampak Perubahan Tutupan Lahan terhadap Kondisi Hidrologi di Das Buol, Kabupaten Buol, Sulawesi Tengah: Simulasi dengan Model Genriver http://dx.doi.org/10.5716/WP17146.PDF

262. Analisis Tapak Mata Air Umbulan, Pasuruan, Jawa Timur. Kajian elemen biofisik dan persepsi masyarakat. http://dx.doi.org/10.5716/WP17147.PDF 
The World Agroforestry Centre is an autonomous, non-profit research organization whose vision is a rural transformation in the developing world as smallholder households increase their use of trees in agricultural landscapes to improve food security, nutrition, income, health, shelter, social cohesion, energy resources and environmental sustainability. The Centre generates science-based knowledge about the diverse roles that trees play in agricultural landscapes, and uses its research to advance policies and practices, and their implementation that benefit the poor and the environment. It aims to ensure that all this is achieved by enhancing the quality of its science work, increasing operational efficiency, building and maintaining strong partnerships, accelerating the use and impact of its research, and promoting greater cohesion, interdependence and alignment within the organization.

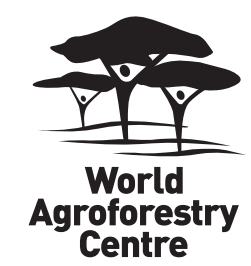

United Nations Avenue, Gigiri • PO Box 30677 • Nairobi, $00100 \cdot$ Kenya Telephone: +254207224000 or via USA +1 6508336645 Fax: +254207224001 or via USA +1 6508336646 Email: worldagroforestry@cgiar.org •www.worldagroforestry.org 